\title{
Integration of a solar cooling and heating system. Case of a residential building located in Blida region
}

\author{
Sabrina Sami ${ }^{1, *}$, Karim $\mathrm{Kaci}^{2}$, Mohamed EL.Ganaoui ${ }^{3}$, Lahoucine Ouhsaine ${ }^{3}$ \\ ${ }^{11}$ Centre de Développement des Energies renouvelables, CDER, Bouzareah, Algiers, Algeria \\ ${ }^{2}$ Université Saad Dahleb Département des Energies Renouvelables ,Soumaa, Blida, Algeria \\ ${ }^{3}$ Université de Lorraine, LERMAB, EA 4370, IUT de Longwy, 54400 Casnes and Romain, France
}

\begin{abstract}
The object of the present study is the integration of a solar cooling and heating system of a residential building (4-flour) located in Blida region in Algeria. The system consists of a set of solar collectors that supply energy to a balloon through an external heat exchanger. The solar and auxiliary tanks are connected by a heat exchanger immersed in the bottom of the auxiliary tank. In the distribution loop, a recirculation can make possible to obtain the domestic hot water set point temperature. A cold production system is directly connected to the solar tank and a regulation system ensures the control of the installation. We have used the TRANSOL software under TRANSYS to calculate the heating and cooling load. Several parameters are then introduced to size and evaluate the performance of our installation. The results obtained are satisfactory .
\end{abstract}

\section{Introduction}

About $40 \%$ of the national energy consumption in Algeria is due to the residential sector. This consumption is increasing continuously because of the increase of housing construction rate and therefore corresponding household equipments including electrical, heating and cooling devices [1].

Several authors have focused their studies on the integration of solar systems into buildings with the main objective of saving energy.For example, X.Q. Zhai et al [2] in Shanghai, studied a heating and cooling solar system with approximately $150 \mathrm{~m}^{2}$ of solar collectors' area, two adsorption chillers and a hot water storage tank of a volume of $2.5 \mathrm{~m}^{3}$. After one year of experimentation, The results confirmed that the solar system contributes by about $70 \%$ of the total energy of the heating space. Ming. Qu et al [3] studied solar cooling and heating system composed of parabolic solar collectors of about $52 \mathrm{~m} 2$ and a lithium bromide $(\mathrm{LiBr})$ absorption chiller. The results showed that this solar thermal system could potentially provide $39 \%$ of cooling and $20 \%$ of heating energy. In their work, P. Hernandez et al, [4] studied the performance of a solar heating and cooling system integrated to an office building located in southern Italy. This analysis, which was done under TRNSYS simulation, gave very promising results. In his paper, Hoy-Yen Chan's [5] proposes a review of passive solar technologies for space heating and cooling and highlights their benefits, limitations and technology challenges as well as future research needs and suggestion.

In Algeria, several authors studied occupant comfort aspect in the housing sector, among them M. Missoum et al [6] and S. Bekkouche et al [7]. Other authors have looked at the integration of solar systems like K. Imessad et al [8] and F. Boudali et al [9]. Concerning the integration of both heating and cooling solar systems, one of the most recent works is the one done by $\mathrm{S}$. Bahria et al [10]. They performed a parametric optimization using dynamic simulation of a solar thermal system for the production of hot water, space heating and cooling. Two types of construction were compared; the first is a typical construction in Algeria, and the second is a building with high-energy performance. Three Algerian regions were considered (Algiers, Djelfa and Tamanrasset). The results showed that the contribution of solar energy is more than $60 \%$. In all cases, they found that the solar fraction reaches more than $45 \%$ when the optimal parameters of the solar system are selected. .In the present contribution, we extend the work done by S. Bahria et al. [10] to the region of Blida, which belongs to the climatic zone B [11], with the specific change of using vacuum collectors integrated in a four levels building instead of flat collectors integrated in a one level construction that has been considered in the paper [10]. The aim is to achieve higher temperatures as the studied buildings have roofs sloping at $21^{\circ}$. The studied building is part of a national pilot project aimed to build 600 housing with high-energy performance [12]. It is a 4-flour building and contains 10 apartments with an area of $67 \mathrm{~m}^{2}$ each. We have used the TRANSOL software under TRANSYS to calculate the heating (space and hot water) and cooling load. Several parameters are then introduced to size and evaluate the performance of our installation.

\footnotetext{
Corresponding author: s.sami@cder.dz
} 


\section{System description}

The system consists of a set of solar collectors that provide energy to the solar flask through an external heat exchanger. The two flasks are connected by a heat exchanger immersed at the bottom of the auxiliary flask. The energy supplied to the auxiliary tank can also come from a hydraulic auxiliary heating through a heat exchanger located in the upper zone of the balloon. In the distribution loop, a recirculation can be used to obtain the DHW set point temperature [10, 13]. The cold machine is directly connected to the solar tank, and operates when a need for air conditioning appears and if the temperature of the tank is higher than the set temperature. The flow through the generator is constant; the fluid is mixed at the inlet to adjust the power of the machine. The return temperature to the tower is kept above the set point by a valve that mixes with the inlet fluid. The flow rate of the cold distribution loop is always variable, with constant inlet and return temperatures. The heating circuit can be fed by hot water from the bottom of the tank, and if necessary directly by the supplement. Temperature and flow can be fixed or variable. The regulation of the primary circuit can be carried out by measuring the sunshine or by measuring a temperature differential $[13]$. (See figure1 $[10,13]$ )

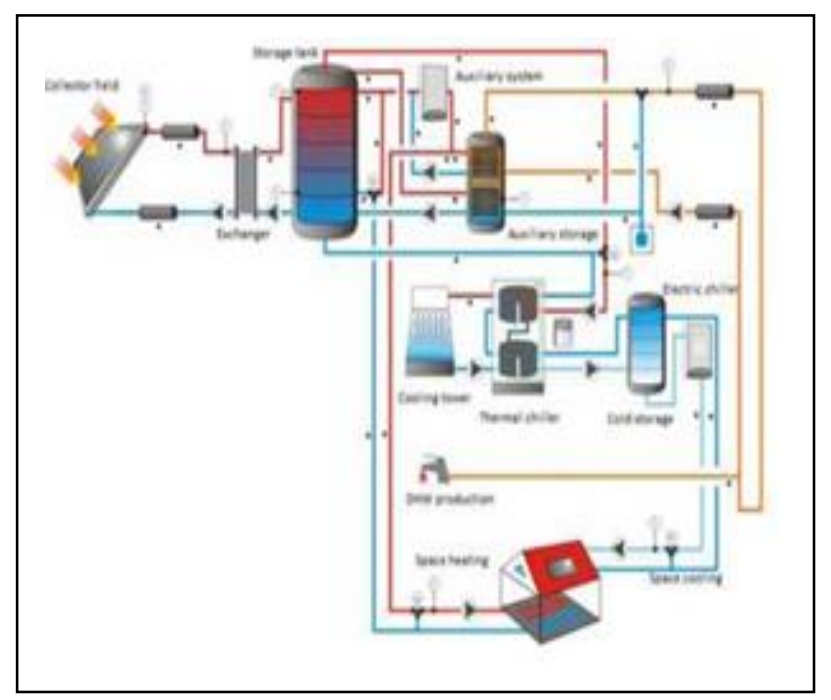

Fig. 1. System description

\subsection{Presentation of the building}

The studied building is part of a national pilot project aimed to build 600 housing with high-energy performance (see figure 2, [14]).

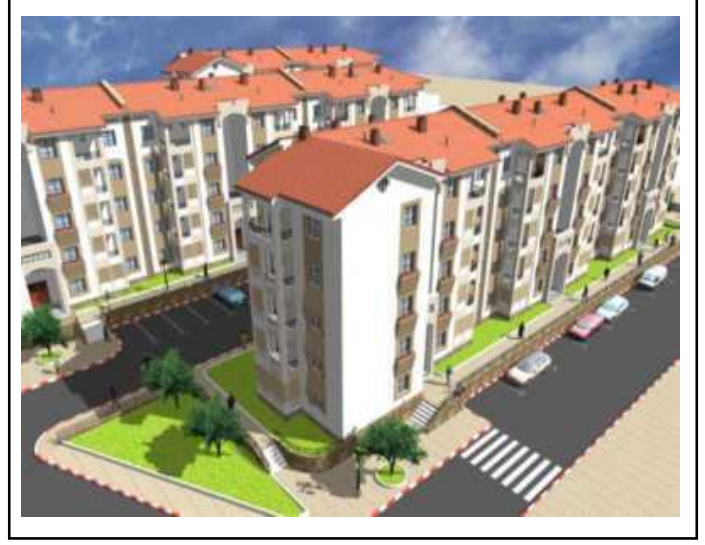

Fig. 2. System description

The 4-flour building contains eight apartments with an area of $67 \mathrm{~m} 2$ each. The figure 3 represent the floor plan.

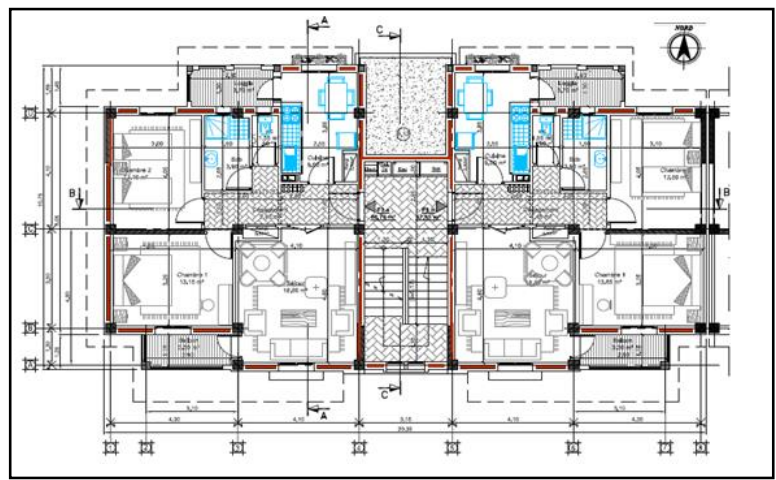

Fig. 3. Floor plan

The following table 1 shows the composition of the building's walls [16].

Table1. Wall's composition

\begin{tabular}{|c|c|c|c|}
\hline & Composition & $\begin{array}{c}\text { Thickness } \\
\text { (m) }\end{array}$ & $\mathbf{R}\left(\mathbf{m}^{2} \cdot{ }^{\circ} \mathrm{c} / \mathbf{W}\right)$ \\
\hline Internal wall & $\begin{array}{c}\text { Mortar } \\
\text { Brick } \\
\text { Polystyrene } \\
\text { Brick } \\
\text { plaster }\end{array}$ & $\begin{array}{l}0.02 \\
0.10 \\
0.05 \\
0.10 \\
0.02\end{array}$ & $\begin{array}{l}0.02 \\
0.21 \\
1.28 \\
0.21 \\
0.06\end{array}$ \\
\hline Eexternal wall & $\begin{array}{c}\text { plaster } \\
\text { brick } \\
\text { plaster }\end{array}$ & $\begin{array}{l}0.02 \\
0.10 \\
0.02\end{array}$ & $\begin{array}{l}0.06 \\
0.21 \\
0.06\end{array}$ \\
\hline Roof & $\begin{array}{l}\text { plaster } \\
\text { hourdi } \\
\text { concrete } \\
\text { polystyrene } \\
\text { mortar } \\
\text { tile }\end{array}$ & $\begin{array}{c}0.015 \\
0.16 \\
0.04 \\
0.10 \\
0.03 \\
0.01 \\
\end{array}$ & $\begin{array}{l}0.04 \\
0.13 \\
0.02 \\
2.56 \\
0.03\end{array}$ \\
\hline Ground & $\begin{array}{c}\text { Plaster } \\
\text { Hourdi } \\
\text { Concret } \\
\text { Polyst } \\
\text { Mortar } \\
\text { tiling }\end{array}$ & $\begin{array}{l}0.015 \\
0.16 \\
0.04 \\
0.10 \\
0.03 \\
0.02\end{array}$ & $\begin{array}{l}0.04 \\
0.13 \\
0.02 \\
2.56 \\
0.03 \\
0.01\end{array}$ \\
\hline
\end{tabular}


The building is located in the town of Blida, which lies within the climatic zone B [11]. Geographic coordinates of Blida are as follows [15]:

Latitude: $36,42^{\circ}$, Longitude: $2,8^{\circ}$, Altitude: $341 \mathrm{~m}$.

\section{Sizing of the installation}

It is not realistic to cover $100 \%$ of hot water and heating needs using only solar energy. A solar energy system will always be coupled with an extra-system using another energy source: gas or electricity. The sizing allows using a solar system and therefore minimizes the contribution the extra-system.

\subsection{Domestic solar hot water needs}

A simple daily and annual sanitary hot water draw profile was chosen, a profile corresponding to an ordinary Algerian family of four persons with heavy consumption at peak hours (7am, noon and $4 \mathrm{pm}$ ). The hot water requirement is 2000 liters/day at a temperature of $45^{\circ} \mathrm{C}$. This consumption corresponds to a ratio of $30 \mathrm{l} / \mathrm{day} /$ person [17].

\subsection{Collector field surface}

The collector surface is the critical variable in the design of such systems, because it determines the useful output of the system. In our case, the collector surface sizing is based on the roof surface. Figure 4 [18] shows the south facade of the building and the roof where we will integrate the collecting field

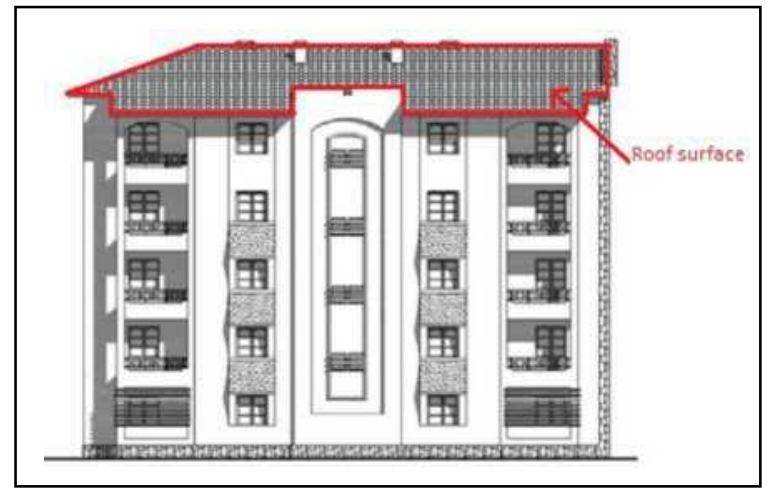

Fig. 4. Roof (south facade)

To calculate the inclination of the roof, we need its dimensions, which are as follows:

Length $=5.9 \mathrm{~m}$, Height $=2.16 \mathrm{~m} \mathrm{[18]}$, the inclination of the roof is $20.10^{\circ}$. The surface provided on the roof is then equal to $100 \mathrm{~m} 2$. According to the ratio used in the literature [19], we use $1 \mathrm{~m}^{2}$ of collecting area for $5 \mathrm{~m}^{2}$ habitable areas. The surface of a single apartment equals $66.75 \mathrm{~m}^{2}$. The living space is equal to $45 \mathrm{~m}^{2}$ and the integration area in the roof is $90 \mathrm{~m}^{2}$. The selected solar collector correspond to a vacuum tube collector due to the need of cooling production in summer period. The collector has an optical efficiency of 0.7 , an overall loss coefficient of $3 \mathrm{~W} / \mathrm{m}^{2} .{ }^{\circ} \mathrm{C}$, and an opening area of $1.2 \mathrm{~m}^{2}$ [13]. Details of the collector field installation are given in Table 2.

Table 2. Collector field details

\begin{tabular}{|l|c|l|c|}
\hline Collectors number & 31 & Number of rows & 3 \\
\hline $\begin{array}{l}\text { The number of } \\
\text { collectors in series }\end{array}$ & 2 & $\begin{array}{l}\text { The distance } \\
\text { between two } \\
\text { collectors in series }\end{array}$ & $0.5 \mathrm{~m}$ \\
\hline $\begin{array}{l}\text { The inclination of } \\
\text { the collectors }\end{array}$ & $20^{\circ}$ & $\begin{array}{l}\text { Net surface of } \\
\text { the collector }\end{array}$ & $2.6 \mathrm{~m}^{2}$ \\
\hline
\end{tabular}

The cooling power is $53 \mathrm{~kW}$, for this reason we chose the power of the machine equal to $70 \mathrm{~kW}$, which is available in the market and can be simulated using the software. The characteristics of the absorption machine are given in Table 3 [13]

Table 3. The characteristics of the absorption machine

\begin{tabular}{|c|c|}
\hline Type & YAZAKI WFC-SC20 \\
\hline Power & $70 \mathrm{KW}$ \\
\hline Cooling water flow & $36.72 \mathrm{~m} 3 / \mathrm{h}$ \\
\hline The pressure drop & $45.3 \mathrm{KPa}$ \\
\hline $\begin{array}{c}\text { Demand for power } \\
\text { Coefficient of } \\
\text { performance }\end{array}$ & $0.26 \mathrm{KW}$ \\
\hline $\begin{array}{c}\text { Power of the cooling } \\
\text { tower }\end{array}$ & 0.7 \\
\hline $\begin{array}{c}\text { The type of the tower } \\
\text { The performance of the } \\
\text { tower }\end{array}$ & $\begin{array}{c}\text { EVAPCO LSWA- } \\
20 \mathrm{AA}\end{array}$ \\
\hline
\end{tabular}

\section{Results and discussion}

The simulation is performed all throughout the year. The network temperature is calculated based on the average annual temperatures. The meteorological data, such as the ambient temperature, the different components of the solar radiation and the humidity, were generated using the Meteonorm 7 software. [20] 


\subsection{Solar fraction Analysis}

\subsubsection{Solar domestic hot water}

The average annual solar fraction found (see Figure 5) is of the order of $72 \%$. A minimum is observed for the month of January, when the solar potential is very low and the energy needs are high. This solar cover for hot water is maximum in summer due to the choice of solar collector technology (vacuum tube collector) as well as the potential of the site.

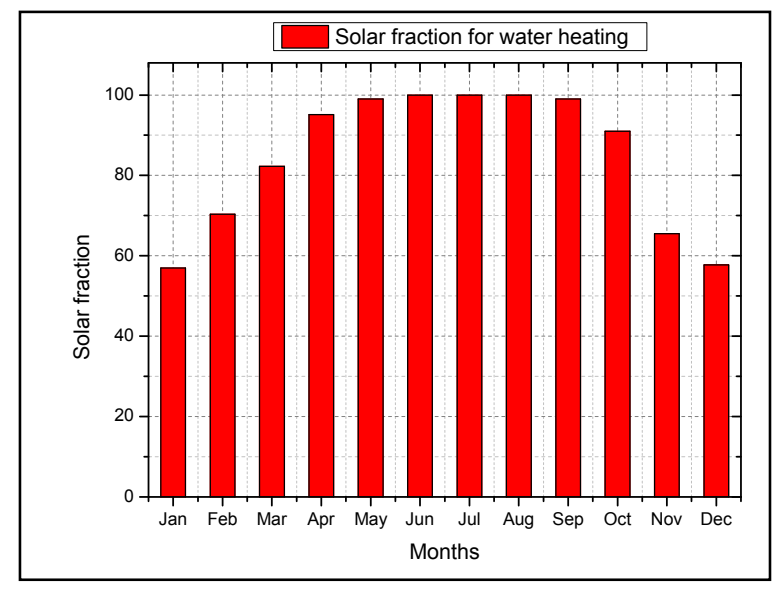

Fig. 5. Solar fraction for water heating system

\subsubsection{Solar heating and cooling space}

Our solar installation, as shown in Figure 6, covers only a fraction of $10 \%$ for the winter months, which is mainly because when the needs are at the maximum, solar inputs are at their minimum. Other reasons lie in the limited roof surface and the imposed choice of its inclination (favorable to summer). This leads to an under-sizing, which will represent a major constraint for such installations. Nevertheless, we can reach $30 \%$ for the months of October, March and April, which represents a relatively significant amount of energy saving.

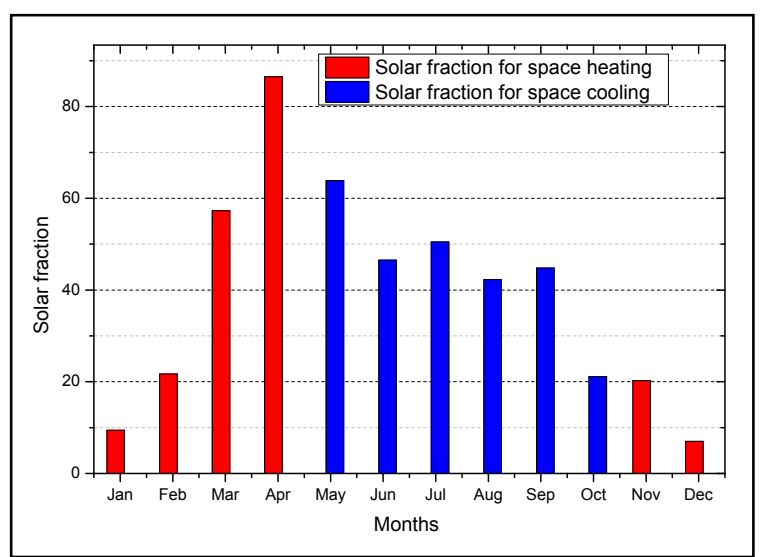

Fig. 6. Solar fraction for space heating and cooling

Regarding the cooling capacity, we note that our solar installation covers almost half of the needs (average solar fraction $50 \%$ ) with a minimum recorded for the month of August corresponding to a fraction of $45 \%$. This solar fraction is very important which, unlike heating, essentially results from the advantage of having needs and contributions in phase (when the needs are at their maximum, the solar contributions are at their maximum), which makes this application very interesting. Not forgetting to mention the judicious choice of vacuum sensors that ensure good operation of the system and a better performance for an absorption machine (water - lithium bromide)

\subsection{Energetic needs analysis}

\subsubsection{Hot water needs}

The annual consumption requirements for domestic hot water are shown in Figure 7. The figure represents the net consumption of domestic hot water according to the months of the year. The needs decrease in summer, with a minimum for the month of August (around $1656 \mathrm{kWh}$ ), which is very low because of the high potential in this period. They however increase for the winter months, where the maximum is reached around $2909 \mathrm{kWh}$ in January. Needs vary according to the habits of the occupants and the period during the year (climate), in addition to the design choice (family of four and an average drawing profile)

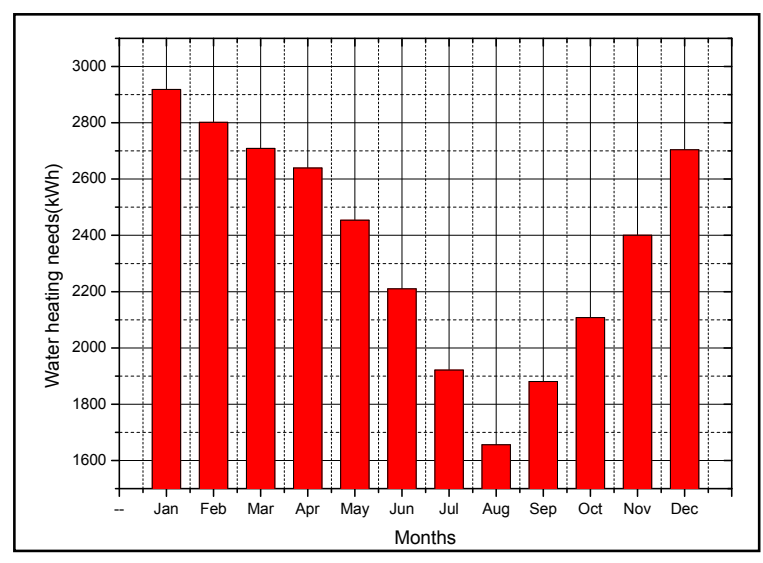

Fig.7. Water heating needs

\subsubsection{Solar Heating and cooling energetic needs}

The annual energy requirements for heating are shown in Figure 8. It should be noted that the heating requirements are almost zero in the summer period; they are at their maximum in winter with values around $2762 \mathrm{kWh}$. These needs are relatively important given the choice of our sizing and the scenario chosen (four people per family). Worth to mention also the low potential in winter for the region of Blida (average temperature in winter is about $10^{\circ} \mathrm{C}$ ).

Cooling needs have a bell shape in summer. We note that the needs for air conditioning are at their peak in July with values around $2200 \mathrm{kWh}$ which is a relatively 
an average value. This can be explained by chosen design of the High Energy Performance (HPE) house, which is characterized by an efficient insulation of its envelope. The minimums are recorded in May, which represents the transition period from heating to cooling.

However, the figure also shows that we have some air conditioning needs for the month of October, which is probably due to the high temperature provided by the Meteonorm software (maximum temperature $24^{\circ} \mathrm{C}$ ) and the climatic zone of this region.

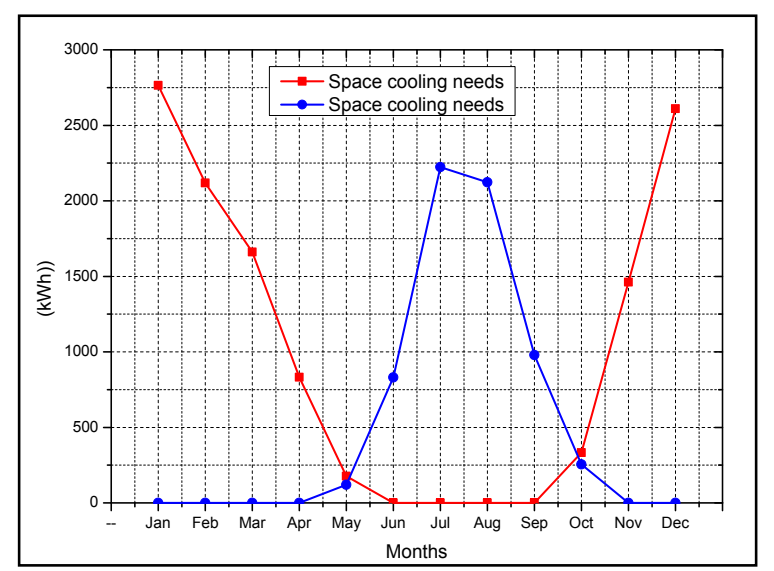

Fig.8. Space Healing and cooling needs

\section{Conclusion}

We have studied a multifunctional solar system (ECS, heating and cooling) using the TRANSOL software in dynamic mode to see the thermal behavior of the studied block after the integration of solar systems. The results showed that the heating requirements are relatively important given the choice of our sizing and the scenario chosen; all associated with the low potential in winter for the region of Blida. Our solar installation covers only a fraction of $10 \%$ for the winter months, which is mainly because when the needs are at their maximum, solar gains are at their minimum. It can also be noted that having a roof slope favorable for the summer season leads to an under-sizing of the system and therefore a major constraint for such installations.

For air conditioning needs, they vary according to the habits of the occupants and the period of year (climate) and the sizing choice (family of 4 people and an average drawing profile). We notice that our solar installation covers almost half (solar fraction average 50\%) for the summer months. We can say that it is an important solar fraction, which is due essentially to the fact, that when the needs are at their maximum, the solar contributions are at their maximum, unlike heating. The fact of using vacuum collectors ensures a better performance for an absorption machine (water - lithium bromide).

For domestic hot water, we note that in summer the contribution of the extra is not even necessary (the coverage is total). This is due to the chosen dimensioning and the type of collector used (vacuum tube collector). The average annual solar fraction is around $72 \%$, which is a very encouraging value.
We can say that these simulations give satisfactory results. The choice of a combined system is very sensible as well as the fact of using solar collectors under vacuum all year long (heating of the habitat in winter, heating of the sanitary water for the rest of the year and cooling in summer).

\section{References}

1. National energy balance 2014, Algerian Ministry of Energy. Edition 2015.

2. X.Q. Zhai, R.Z. Wang. Experiences on solar heating and cooling in China. Renewable and Sustainable Energy Reviews 12 (2008) 1110-1128

3. Ming Qu, Hongxi Yin, David H. Archer. A solar thermal cooling and heating system for a building: Experimental and model based performance analysis and design. Solar Energy 84 (2010) 166182.

4. Patxi Hernandez, Paul Kenny.Net energy analysis of domestic solar water heating installations in operation. Renewable and Sustainable Energy Reviews 16 (2012) 170- 177.

5. Hoy-Yen Chan, Saffa B. Riffat, Jie Zhu .Review of passive solar heating and cooling technologies. Renewable and Sustainable Energy Reviews 14 (2010)781-789

6. M.Missoum, A.Hamidat, L.Loukarfi,K.Abdeladim. Impact of rural housing energy performance improvement on the energy balance in the northwest of Algeria. Energy and Buildings, Volume 85(2014)374-388

7. S.M.A. Bekkouche, T. Benouaz, M. Hamdani, M.K. Cherier, M.R. Yaiche, N. Benamrane. Judicious choice of the building materials and their effect upon the interior temperatures. Case of building located in Ghardaia region. Journal of Building Engineering 1(2015) 42-52.

8. K. Imessad, L. Derradji, N.Ait Messaoudene, F. Mokhtari , A. Chenak , R. Kharchi Impact of passive cooling techniques on energy demand for residential building $\mathrm{s}$ in a Mediterranean climate. Renewable energy 71 (2014) .589-597

9. Farid Boudali Errebai, Lotfi.Derradji, Mohamed Amara. Thermal behaviour of a dwelling heated by different heating systems. Energy Procedia. 107 (2017)144-149

10. S.Bahria, M. Amirat, A. Hamidat, M. E. Ganaoui, M. Slimani. Parametric study of solar heating and cooling systems in different climates of Algeria - A comparison between conventional and high-energyperformance buildings, Energy 113 (2016) 521 535.

11. Regulatory Technical Documents DTR Algerian Ministry of Housing- CNERIB 2017

12. ECO-BAT project, Algerian Ministry of Energy, National Agency for the Promotion and Rationalization of Energy Use - APRUE- 
13. Transol solar thermal energy software. Aiguasol 2013.

14. Document project of the Algerian office of Promotion and immovable management (OPGI)

15. Yaiche MR, Bouhanik A. Atlas solaire Algerien. Centre de Developpement des Energies Renouvelables ; 2013.

16. S.Sami Mecheri et al. Simulation and comparison of energy requirements of a conventional housing, a HEP housing and reinforced insulation housing: Application to the region of Tamanrasset (Algeria). 'Entech 13', Istanbul- Turkey, 2013.

17. J.A. Duffie, W.A. Beckman: «Solar Engineering of thermal Process» Fourth edition 2013.

18. S. Sami Mecheri et al. Integration of a heating system in Algeria-Application to an HPE building located in climatic zone B. ICES'15. IstanbulTurkey, 2015.

19. Thierry Cabirol, Daniel Roux. Chauffage de L'habitat et energie solaire. Edisud, 1984.

20. "Meteonorm Software 7.0," 2014. [Online]. Available: http: //meteonorm .com/en/. 